\title{
2008 Data
}

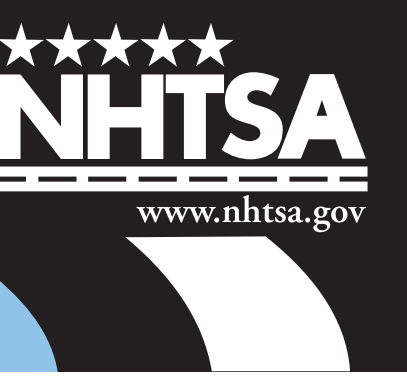

DOT HS 811156

\section{Bicyclists and Other Cyclists}

"The 716 bicyclist

deaths in 2008

accounted for 2 percent

of all traffic fatalities

during the year."
Bicyclists and other cyclists include riders of two-wheel nonmotorized vehicles, tricycles, and unicycles powered solely by pedals. Throughout the remainder of this fact sheet the term pedalcyclists will be used to identify these cyclists.

The first automobile crash in the United States occurred in New York City in 1896, when a motor vehicle collided with a pedalcycle rider (Famous First Facts, by Joseph Kane). About 53,000 pedalcyclists have died in traffic crashes in the United States since 1932 - the first year in which estimates of pedalcyclist fatalities were recorded. The 350 pedalcyclists killed in 1932 accounted for 1.3 percent of the 27,979 persons who died in traffic crashes that year.

In 2008, 716 pedalcyclists were killed and an additional 52,000 were injured in traffic crashes. Pedalcyclist deaths accounted for 2 percent of all traffic fatalities, and pedalcyclists made up 2 percent of all the people injured in traffic crashes during the year.

The number of pedalcyclist fatalities in 2008 is 6 percent lower than the 760 fatalities reported in 1998. The highest number of pedalcyclist fatalities ever recorded in the Fatality Analysis Reporting System (FARS) was 1,003 in 1975. Pedalcyclists accounted for 14 percent of all nonoccupant traffic fatalities in 2008.

Figure 1

Total Pedalcyclist Fatalities, 1998-2008

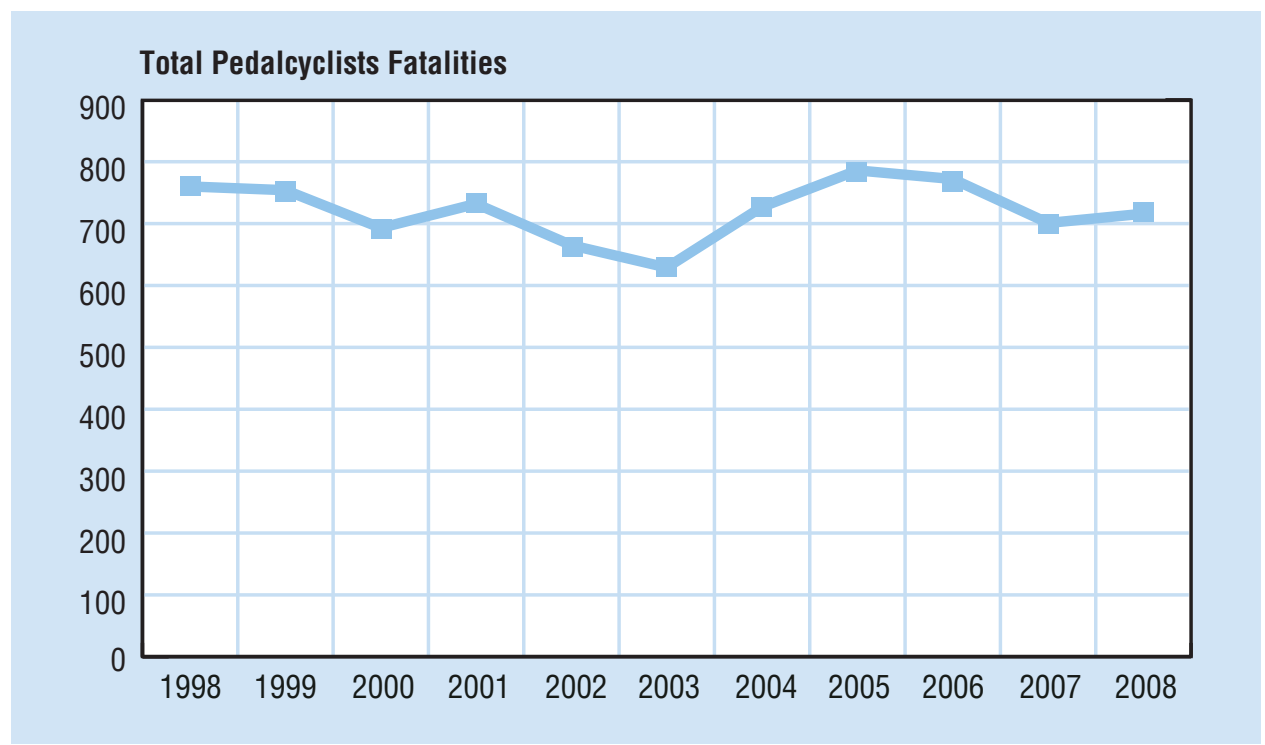




\section{"One-seventh of the pedalcyclists killed in traffic crashes in 2008 were between 5 and 15 years old."}

Table 1

Nonoccupant Traffic Fatalities, 1998-2008

\begin{tabular}{c|c|c|c|c}
\hline Year & Pedalcyclist & Pedestrian & Other & Total \\
\hline 1998 & 760 & 5,228 & 131 & 6,119 \\
\hline 1999 & 754 & 4,939 & 149 & 5,842 \\
\hline 2000 & 693 & 4,763 & 141 & 5,597 \\
\hline 2001 & 732 & 4,901 & 123 & 5,756 \\
\hline 2002 & 665 & 4,851 & 114 & 5,630 \\
\hline 2003 & 629 & 4,774 & 140 & 5,543 \\
\hline 2004 & 727 & 4,675 & 130 & 5,532 \\
\hline 2005 & 786 & 4,892 & 186 & 5,864 \\
\hline 2006 & 772 & 4,795 & 185 & 5,752 \\
\hline 2007 & 701 & 4,699 & 158 & 5,558 \\
\hline 2008 & 716 & 4,378 & 188 & 5,282 \\
\hline
\end{tabular}

Pedalcyclist fatalities occurred more frequently in urban areas (69\%), at nonintersection locations (64\%), between the hours of 5 p.m. and 9 p.m. $(28 \%)$, and during the months of June (9\%) and September (12\%).

\section{Age}

In 1998, the average age of pedalcyclists killed in traffic crashes was 32; in 2008 the average age of those killed was 41. In contrast, in 1998 the average age of those injured was 24 and the average age of those injured in 2008 was 31.

Table 2

\section{Average Age of Pedalcyclists Killed and Injured, 1998-2008}

\begin{tabular}{c|c|c}
\hline Year & Pedalcyclists Killed Average Age & Pedalcyclists Injured Average Age \\
\hline 1998 & 32 & 24 \\
\hline 1999 & 33 & 24 \\
\hline 2000 & 35 & 25 \\
\hline 2001 & 36 & 26 \\
\hline 2002 & 37 & 28 \\
\hline 2003 & 36 & 27 \\
\hline 2004 & 39 & 29 \\
\hline 2005 & 39 & 29 \\
\hline 2006 & 41 & 30 \\
\hline 2007 & 40 & 31 \\
\hline 2008 & 41 & 31 \\
\hline $1998-2008$ & 37 & 28 \\
\hline
\end{tabular}

Pedalcyclists under age 16 accounted for 13 percent of all pedalcyclists killed and 25 percent of those injured in traffic crashes in 2008. By comparison, pedalcyclists under age 16 accounted for 30 percent of all those killed and 44 percent of those injured in 1998.

Pedalcyclists age 25 and older have made up an increasing proportion of all pedalcyclist deaths since 1998. The proportion of pedalcyclist fatalities age 25 to 64 was 1.3 times higher in 2008 as in 1998 (64\% and 50\%, respectively).

About one-seventh (12\%) of the pedalcyclists killed in traffic crashes in 2008 were between 5 and 15 years old. The pedalcyclist fatality rate for this age group in 2008 was 2.01 per million population - about 14 percent lower than the rate for all pedalcyclists ( 2.35 per million population). The injury rate for this age group was 293 per million population, compared with 172.3 per million population for pedalcyclists of all ages. 


\section{Alcohol-Related Data}

Alcohol involvement - either for the driver or the pedalcyclist - was reported in more than one-third (37\%) of the traffic crashes that resulted in pedalcyclist fatalities in 2008. In 31 percent of the crashes, either the driver or the pedalcyclist was reported to have a blood alcohol concentration (BAC) of .08 grams per deciliter $(\mathrm{g} / \mathrm{dL})$ or higher. Lower alcohol levels (BAC .01 to .07 g/ dL) were reported in an additional 8 percent of crashes. Over one-fourth $(28 \%)$ of the pedalcyclists killed had a BAC of $.01 \mathrm{~g} / \mathrm{dL}$ or higher, and nearly one-fourth (23\%) had a $\mathrm{BAC}$ of $.08 \mathrm{~g} / \mathrm{dL}$ or higher.

\section{Gender}

Most of the pedalcyclists killed or injured in 2008 were males $(87 \%$ and $79 \%$, respectively), and most were between the ages of 5 and $44(48 \%$ and $77 \%$, respectively).

In 2008, the pedalcyclist fatality rate per capita was eight times higher for males than for females, and the injury rate per capita was more than four times higher for males.
"Alcohol involvement was reported in more than one-third of all pedalcyclist fatalities in 2008."

Table 3

Pedalcyclists Killed and Injured and Fatality and Injury Rates by Age and Sex, 2008

\begin{tabular}{|c|c|c|c|c|c|c|c|c|c|}
\hline \multirow[b]{2}{*}{$\begin{array}{c}\text { Age } \\
\text { (Years) }\end{array}$} & \multicolumn{3}{|c|}{ Male } & \multicolumn{3}{|c|}{ Female } & \multicolumn{3}{|c|}{ Total } \\
\hline & Killed & $\begin{array}{c}\text { Population } \\
\text { (thousands) }\end{array}$ & $\begin{array}{c}\text { Fatality } \\
\text { Rate * }^{*}\end{array}$ & Killed & $\begin{array}{c}\text { Population } \\
\text { (thousands) }\end{array}$ & $\begin{array}{c}\text { Fatality } \\
\text { Rate* }\end{array}$ & Killed & $\begin{array}{c}\text { Population } \\
\text { (thousands) }\end{array}$ & $\begin{array}{c}\text { Fatality } \\
\text { Rate* }\end{array}$ \\
\hline$<5$ & 5 & 10,748 & 0.47 & 1 & 10,258 & 0.10 & 6 & 21,006 & 0.29 \\
\hline $5-9$ & 13 & 10,259 & 1.27 & 10 & 9,806 & 1.02 & 23 & 20,065 & 1.15 \\
\hline $10-15$ & 55 & 12,415 & 4.43 & 11 & 11,839 & 0.93 & 66 & 24,255 & 2.72 \\
\hline $16-20$ & 47 & 11,039 & 4.26 & 5 & 10,492 & 0.48 & 52 & 21,531 & 2.42 \\
\hline $21-24$ & 37 & 8,681 & 4.26 & 5 & 8,162 & 0.61 & 42 & 16,842 & 2.49 \\
\hline $25-34$ & 61 & 20,900 & 2.92 & 13 & 20,032 & 0.65 & 74 & 40,932 & 1.81 \\
\hline $35-44$ & 77 & 21,314 & 3.61 & 13 & 21,187 & 0.61 & 90 & 42,501 & 2.12 \\
\hline $45-54$ & 161 & 21,853 & 7.37 & 19 & 22,519 & 0.84 & 180 & 44,372 & 4.06 \\
\hline $55-64$ & 103 & 16,251 & 6.34 & 9 & 17,436 & 0.52 & 112 & 33,686 & 3.32 \\
\hline $65-74$ & 34 & 9,265 & 3.67 & 2 & 10,858 & 0.18 & 36 & 20,123 & 1.79 \\
\hline $75-84$ & 21 & 5,336 & 3.94 & 3 & 7,689 & 0.39 & 24 & 13,025 & 1.84 \\
\hline $85+$ & 5 & 1,864 & 2.68 & 2 & 3,858 & 0.52 & 7 & 5,722 & 1.22 \\
\hline Total & 623 & 149,925 & 4.16 & 93 & 154,135 & 0.60 & 716 & 304,060 & 2.35 \\
\hline \multirow[b]{2}{*}{$\begin{array}{c}\text { Age } \\
\text { (Years) }\end{array}$} & \multicolumn{3}{|c|}{ Male } & \multicolumn{3}{|c|}{ Female } & \multicolumn{3}{|c|}{ Total } \\
\hline & Injured & $\begin{array}{c}\text { Population } \\
\text { (thousands) }\end{array}$ & Injury Rate* & Injured & $\begin{array}{c}\text { Population } \\
\text { (thousands) }\end{array}$ & Injury Rate* & Injured & $\begin{array}{c}\text { Population } \\
\text { (thousands) }\end{array}$ & Injury Rate* \\
\hline$<5$ & 0 & 10,748 & 8.01 & ** & 10,258 & 3.49 & ** & 21,006 & 5.80 \\
\hline $5-9$ & 2,000 & 10,259 & 235.8 & 1,000 & 9,806 & 54.56 & 3,000 & 20,065 & 147.2 \\
\hline $10-15$ & 7,000 & 12,415 & 579.7 & 3,000 & 11,839 & 221.9 & 10,000 & 24,255 & 405.1 \\
\hline $16-20$ & 7,000 & 11,039 & 601.1 & 2,000 & 10,492 & 150.9 & 8,000 & 21,531 & 381.7 \\
\hline $21-24$ & 4,000 & 8,681 & 409.4 & 2,000 & 8,162 & 203.7 & 5,000 & 16,842 & 309.7 \\
\hline $25-34$ & 5,000 & 20,900 & 239.1 & 2,000 & 20,032 & 93.13 & 7,000 & 40,932 & 167.7 \\
\hline $35-44$ & 5,000 & 21,314 & 237.5 & 2,000 & 21,187 & 103.0 & 7,000 & 42,501 & 170.5 \\
\hline $45-54$ & 5,000 & 21,853 & 232.0 & 1,000 & 22,519 & 40.20 & 6,000 & 44,372 & 134.7 \\
\hline $55-64$ & 4,000 & 16,251 & 218.4 & $\star \star$ & 17,436 & 17.42 & 4,000 & 33,686 & 114.4 \\
\hline $65-74$ & 1,000 & 9,265 & 127.7 & ** & 10,858 & 3.71 & 1,000 & 20,123 & 60.80 \\
\hline $75-84$ & 1,000 & 5,336 & 141.7 & ** & 7,689 & 7.12 & 1,000 & 13,025 & 62.24 \\
\hline $85+$ & $\star \star$ & 1,864 & 47.48 & $\star \star \star$ & 3,858 & 0.00 & $\star *$ & 5,722 & 15.46 \\
\hline Total & 41,000 & 149,925 & 270.8 & 12,000 & 154,135 & 76.54 & 52,000 & 304,060 & 172.3 \\
\hline
\end{tabular}

* Rate per million population.

** Less than 500 injured.

Source: Population - Bureau of the Census projections. 
Table 4

Pedalcyclist Traffic Fatalities and Fatality Rates by State, 2008

\begin{tabular}{|c|c|c|c|c|c|}
\hline State & Total Traffic Fatalities & $\begin{array}{l}\text { Resident Population } \\
\text { (thousands) }\end{array}$ & Pedalcyclist Fatalities & Percent of Total & $\begin{array}{l}\text { Pedalcyclist Fatalities } \\
\text { per Million Population }\end{array}$ \\
\hline Alabama & 966 & 4,662 & 4 & 0.4 & 0.86 \\
\hline Alaska & 62 & 686 & 1 & 1.6 & 1.46 \\
\hline Arizona & 937 & 6,500 & 19 & 2.0 & 2.92 \\
\hline Arkansas & 600 & 2,855 & 5 & 0.8 & 1.75 \\
\hline California & 3,434 & 36,757 & 109 & 3.2 & 2.97 \\
\hline Colorado & 548 & 4,939 & 12 & 2.2 & 2.43 \\
\hline Connecticut & 264 & 3,501 & 5 & 1.9 & 1.43 \\
\hline Delaware & 121 & 873 & 6 & 5.0 & 6.87 \\
\hline District of Columbia & 34 & 592 & 1 & 2.9 & 1.69 \\
\hline Florida & 2,978 & 18,328 & 125 & 4.2 & 6.82 \\
\hline Georgia & 1,493 & 9,686 & 20 & 1.3 & 2.06 \\
\hline Hawaii & 107 & 1,288 & 2 & 1.9 & 1.55 \\
\hline Idaho & 232 & 1,524 & 2 & 0.9 & 1.31 \\
\hline Illinois & 1,043 & 12,902 & 27 & 2.6 & 2.09 \\
\hline Indiana & 814 & 6,377 & 18 & 2.2 & 2.82 \\
\hline lowa & 412 & 3,003 & 5 & 1.2 & 1.67 \\
\hline Kansas & 385 & 2,802 & 6 & 1.6 & 2.14 \\
\hline Kentucky & 826 & 4,269 & 6 & 0.7 & 1.41 \\
\hline Louisiana & 912 & 4,411 & 11 & 1.2 & 2.49 \\
\hline Maine & 155 & 1,316 & 4 & 2.6 & 3.04 \\
\hline Maryland & 591 & 5,634 & 6 & 1.0 & 1.07 \\
\hline Massachusetts & 363 & 6,498 & 10 & 2.8 & 1.54 \\
\hline Michigan & 980 & 10,003 & 25 & 2.6 & 2.50 \\
\hline Minnesota & 456 & 5,220 & 13 & 2.9 & 2.49 \\
\hline Mississippi & 783 & 2,939 & 4 & 0.5 & 1.36 \\
\hline Missouri & 960 & 5,912 & 3 & 0.3 & 0.51 \\
\hline Montana & 229 & 967 & 3 & 1.3 & 3.10 \\
\hline Nebraska & 208 & 1,783 & 0 & 0 & 0 \\
\hline Nevada & 324 & 2,600 & 7 & 2.2 & 2.69 \\
\hline New Hampshire & 139 & 1,316 & 2 & 1.4 & 1.52 \\
\hline New Jersey & 590 & 8,683 & 20 & 3.4 & 2.30 \\
\hline New Mexico & 366 & 1,984 & 7 & 1.9 & 3.53 \\
\hline New York & 1,231 & 19,490 & 42 & 3.4 & 2.15 \\
\hline North Carolina & 1,433 & 9,222 & 32 & 2.2 & 3.47 \\
\hline North Dakota & 104 & 641 & 1 & 1.0 & 1.56 \\
\hline Ohio & 1,190 & 11,486 & 18 & 1.5 & 1.57 \\
\hline Oklahoma & 749 & 3,642 & 4 & 0.5 & 1.10 \\
\hline Oregon & 416 & 3,790 & 10 & 2.4 & 2.64 \\
\hline Pennsylvania & 1,468 & 12,448 & 8 & 0.5 & 0.64 \\
\hline Rhode Island & 65 & 1,051 & 1 & 1.5 & 0.95 \\
\hline South Carolina & 920 & 4,480 & 14 & 1.5 & 3.13 \\
\hline South Dakota & 119 & 804 & 0 & 0 & 0 \\
\hline Tennessee & 1,035 & 6,215 & 7 & 0.7 & 1.13 \\
\hline Texas & 3,382 & 24,327 & 53 & 1.6 & 2.18 \\
\hline Utah & 275 & 2,736 & 4 & 1.5 & 1.46 \\
\hline Vermont & 73 & 621 & 0 & 0 & 0 \\
\hline Virginia & 824 & 7,769 & 13 & 1.6 & 1.67 \\
\hline Washington & 521 & 6,549 & 9 & 1.7 & 1.37 \\
\hline West Virginia & 380 & 1,814 & 2 & 0.5 & 1.10 \\
\hline Wisconsin & 605 & 5,628 & 9 & 1.5 & 1.60 \\
\hline Wyoming & 159 & 533 & 1 & 0.6 & 1.88 \\
\hline U.S. Total* & 37,261 & 304,060 & 716 & 1.9 & 2.35 \\
\hline Puerto Rico & 399 & 3,954 & 12 & 3.0 & 3.03 \\
\hline
\end{tabular}

* Totals may not equal sum of components due to independent rounding.

Sources: Fatalities - Fatality Analysis Reporting System, NHTSA. Population — Bureau of the Census. 


\section{Important Safety Reminders}

All bicyclists should wear properly fitted bicycle helmets every time they ride. A helmet is the single most effective way to prevent head injury resulting from a bicycle crash.

Bicyclists are considered vehicle operators; they are required to obey the same rules of the road as other vehicle operators, including obeying traffic signs, signals, and lane markings. When cycling in the street, cyclists must ride in the same direction as traffic.

Drivers of motor vehicles need to share the road with bicyclists. Be courteous - allow at least three feet clearance when passing a bicyclist on the road, look for cyclists before opening a car door or pulling out from a parking space, and yield to cyclists at intersections and as directed by signs and signals. Be especially watchful for cyclists when making turns, either left or right.

Bicyclists should increase their visibility to drivers by wearing fluorescent or brightly colored clothing during the day, dawn, and dusk. To be noticed when riding at night, use a front light and a red reflector or flashing rear light, and use retro-reflective tape or markings on equipment or clothing.

\section{For more information:}

Information on traffic fatalities is available from the National Center for Statistics and Analysis, NVS-424, 1200 New Jersey Avenue SE., Washington, DC 20590. NCSA can be contacted at 800-934-8517. Fax messages should be sent to 202-366-7078. General information on highway traffic safety can be accessed by Internet users at www.nhtsa.gov/portal/site/nhtsa/ncsa. To report a safety-related problem or to inquire about motor vehicle safety information, contact the Vehicle Safety Hotline at 888-327-4236.

Other fact sheets available from the National Center for Statistics and Analysis are Overview, Alcohol, African American, Children, Hispanic, Large Trucks, Motorcycles, Occupant Protection, Older Population, Pedestrians, Race and Ethnicity, Rural/Urban Comparisons, School Transportation-Related Crashes, Speeding, State Alcohol Estimates, State Traffic Data, and Young Drivers. Detailed data on motor vehicle traffic crashes are published annually in Traffic Safety Facts: A Compilation of Motor Vehicle Crash Data from the Fatality Analysis Reporting System and the General Estimates System. The fact sheets and annual Traffic Safety Facts report can be accessed online at www-nrd.nhtsa.dot.gov/CATS/index.aspx. 